\title{
The detection of HPV DNA, the size of tampon specimens and the menstrual cycle
}

Christopher K Fairley, Priscilla M Robinson, Shujun Chen, Sepher N Tabrizi, Suzanne M Garland

\begin{abstract}
Objective-To determine if HPV detection or the size of a tampon specimen is affected by the menstrual cycle.

Materials-Two hundred and eighty women between 18-35 years of age attending a gynaecology clinic at The Royal Women's Hospital were enrolled. Each woman completed a questionnaire on the risk factors of HPV infection and provided a tampon specimen. Specimens were analysed for the presence of HPV DNA (polymerase chain reaction with the L1 consensus primers) after the pellet volume and number of cells was assessed. Results-The mean age of the 298 women enrolled in this study was $27 \cdot 0$ years (SD 4.5 , range $18-35)$. Ninety two (30.9\%) of the tampon specimens were positive for HPV using the $L 1$ consensus primer. The detection of HPV DNA was not associated with the quartiles of the menstrual cycle $(p=0.32)$. Both the pellet volume and the number of cells from a tampon specimen were greater during the mid cycle, although this was significant for the pellet volume only $(p=0.002$ and 0.1 respectively). The pellet volume was not significantly associated with other variables assessed by the questionnaire. The number of cells from a tampon specimen increased with the numbers of life time sexual partners $(p=0.02)$ and was higher for a single marital status $(p=0.0008)$. Conclusion-The timing of the menstrual cycle effects the size of tampon specimens but not the probability of detecting HPV DNA.
\end{abstract}

and Preventive

Medicine, Monash

University, Alfred

Hospital, Prahran,

Victoria, Australia

C K Fairley

P M Robinson

Department of

Microbiology, The

Royal Women's

Hospital, Carlton,

Victoria, Australia

C K Fairley

P M Robinson

$S$ Chen

S N Tabrizi

S M Garland

Correspondence to:

D C K Fairley, Department

of Social and Preventive

Medicine, Monash

University, Alfred Hospital,

Commercial Road, Prahran,

Victoria 3181 Australia.

Accepted for publication

7 February 1994
(Genitourin Med 1994;70:171-174)

\section{Introduction}

Recent reports indicate that a single genital specimen may underestimate the true prevalence of HPV infection. This is illustrated by one study of 21 women where the point prevalence of HPV type $16(14 \cdot 3-33 \cdot 3 \%)$ was lower than the cumulative prevalence $(66.7 \%) .^{1}$ Intermittent detection of HPV is also reported by other investigators. ${ }^{23}$

Fluctuations in hormone levels associated with the menstrual cycle may affect the detection of HPV. For example, oestrogen promotes cellular differentiation and exfoliation of the superficial cells, while progesterone causes these cells to agglutinate and exfoliate at the intermediate or less differentiated layer. ${ }^{4}$ As the differentiated cells contain the largest amount of complete HPV virions, it is possible that changes in these hormones may influence the chance of detecting HPV during the menstrual cycle. ${ }^{5} \mathrm{~A}$ number of more direct mechanisms by which hormonal changes may influence HPV expression have been suggested, and include hormonal perturbation of the immune response, and steroid-responsive regulation of HPV activity. ${ }^{67}$

Our earlier study did not identify HPV more commonly at different times of the menstrual cycle although the prevalence of HPV was too low for meaningful conclusions to be drawn. ${ }^{8}$ Using a population with a higher expected prevalence of HPV, our aim was to determine if HPV detection or the size of a tampon specimen varied during the menstrual cycle.

\section{Methods}

The study population was selected from women attending a gynaecology clinic at The Royal Women's Hospital Melbourne, between September 1992 and February 1993. Women were considered eligible for the study if they were between 18-35 years of age, used tampons and spoke English. During this period, 620 women were between 18 and 35 years of age, but 69 of these did not speak English. Of the remaining 551, 383 were approached by a research nurse before they left the clinic. Sixty eight of these women did not use tampons, leaving 315 eligible women, of whom 298 agreed to participate. The women whom the research nurse approached $(n=383$ ) were marginally younger than those whom she did not approach $(n=168)(26.9$ years $v 27.8$ years, $p=0.05)$. This study formed part of a larger project assessing the risk factors for HPV among tampon users (unpublished observations Fairley et al). The research protocol was approved by the Ethics Committee at The Royal Women's Hospital and each woman gave written informed consent.

Each woman completed a self answer questionnaire, and provided a single tampon specimen (in/out specimen). The tampon was placed in a container with $15 \mathrm{ml}$ of transport medium (TM) (transport medium; $10 \mathrm{mM}$ Tris- $\mathrm{HCl}, 50 \mathrm{mM}$ EDTA, $150 \mathrm{mM} \mathrm{NaCl}$. $0 \cdot 1 \% \mathrm{NaN}_{3} . \mathrm{pH} 7 \cdot 5$ ). The questionnaire inquired about factors known to be associated with HPV detection including: age, details of the menstrual cycle, marital status, education, smoking, past and current pregnancy, past 
and current Papanicolaou smear result, use of oral contraceptive pill, age at first intercourse, and the number of life time sexual partners. Detailed analysis of how these variables are associated with the presence of HPV DNA is presented elsewhere (unpublished observations, Fairley et al.). The quartile of the menstrual cycle during which the specimens were collected was calculated by dividing the day of the cycle by the average length of each particular woman's cycle. If this figure was greater than one it was not possible to determine the quartile of the cycle.

\section{HPV DNA detection}

The cells were dislodged from the tampons by squeezing and the volume of fluid measured. A drop was then placed on a Neubauer counting chamber to determine the number of cells per $\mathrm{ml}$. The number of cells in the sample was calculated by multiplying the number of cells per $\mathrm{ml}$ by the volume of the pre-spun sample. The remaining sample was pelleted by centrifugation. The "pellet volume" refers to the visualised volume of the spun pellet as measured in calibrated centrifuge tubes. Cell pellets were then stored at $-20^{\circ} \mathrm{C}$ until analysis. DNA was extracted from a $25 \mu \mathrm{l}$ aliquot of the cell pellet by protein $\mathrm{K}$ digestion followed by phenol-chloroform extraction using Contamination Safe mini-DNA Extraction Kit (Salus Scientific. VIC. Australia)..$^{9}$ A $2 \mu \mathrm{l}$ aliquot $(1 / 25$ th) of this was then subjected to DNA amplification. All sample preparation and subsequent polymerase chain reaction (PCR) was carried out in a class II biohazard hood in a room separate from that for analysis of PCR products.

The PCR and subsequent probing was carried out under conditions described by Resnick et al, with minor modifications. ${ }^{10}$ Briefly, the reaction was set in a $50 \mu$ l volume and subjected to 35 cycles with 1 minute for each step. All specimens were amplified with HPV L1 consensus primer set (MY09-MY11) and $\beta$-globin primer set (GH20-PC04). ${ }^{10}$ Southern blotting was carried out using $10 \mu \mathrm{l}$ of PCR products and probed by $\gamma^{32} \mathrm{P}-\mathrm{ATP}$ labelled HPV L1 generic probe. ${ }^{10}$

Cervical cells from previously tested and HPV negative patients were interposed among specimens throughout DNA extraction and PCR to serve as negative controls. In addition a reaction mixture without DNA was included in every PCR run. Positive controls were HeLa cells and cloned HPV DNA type $6,11,16$ and 18 .

\section{Statistical methods}

A chi square or Fisher's exact test was used to determine significant differences between categorical variables. For continuous variables a $t$ test or Mann-Whitney test was used or an analysis of variance (ANOVA) or KruskalWallis test, if more than two variables were being assessed. A Spearman rank correlation was used to determine the relationship between the pellet volume and number of cells. Multiple regression was used to determine if the number of cells in a tampon specimen was independently related to a single marital status and the number of lifetime sexual partners.

\section{Results}

The mean age of the 298 women enrolled in this study was 27.0 years (SD $4 \cdot 5$, range 18-35). Tampon specimens were available from all patients but questionnaires were not returned from eight patients. Ninety two $(30.9 \%)$ specimens were positive for HPV using the $\mathrm{L} 1$ consensus primers. The proportion of samples with HPV DNA detected (26-46\%) was not significantly different during any quartile of the menstrual cycle $(p=$ 0.15 if those where the quartile of the cycle could not be determined are included and $\mathrm{p}=$ 0.31 if this group is excluded) (table 1 ).

The size of the cell pellet and number of cells from a tampon specimen were closely associated (Spearman correlation coefficient, $0.58, \mathrm{p}<0.0001)$. Both the pellet volume and the number of cells from a tampon specimen were greater during the mid cycle, although this was significant for the pellet volume only $(p=0.002$ and 0.1 respectively) (table 1). The difference between the pellet volume during each quartile of the menstrual cycle was investigated. A p value of 0.008 $(0.05 / 6=0.008)$ was used as a significant level to account for the effect of repeating the $t$ test six times. Quartile (Q) $1 v \mathbf{Q} 2$ and Q1 $v$ Q3 were different at this level of significance, while $\mathrm{Q} 1 v \mathrm{Q} 4, \mathrm{Q} 2 v \mathrm{Q} 3, \mathrm{Q} 2 v \mathrm{Q} 4$ and $\mathrm{Q} 3 v$ Q4 were not different $(p=0.003,0.001$,

Table 1 HPV result, pollet volume and number of cells in tampon specimen during different quartiles of the menstrual cycle

\begin{tabular}{llllllll}
\hline $\begin{array}{l}\text { Quartile of } \\
\text { menstrual cycle }\end{array}$ & $\begin{array}{l}\text { HPV } \\
\text { Positive* } \\
(\%) \ddagger\end{array}$ & $\begin{array}{l}\text { HPV } \\
\text { Negative } \\
(\%) \ddagger\end{array}$ & $\begin{array}{l}\text { Number } \\
n=298\end{array}$ & $\begin{array}{l}\text { Mean pellet } \\
\text { volume } \\
\left(\times 10^{-2} \mathrm{ml}\right)\end{array}$ & $S D$ & $\begin{array}{l}\text { Mean number } \\
\text { of cellst } \\
\left(\times 10^{5} \text { per ml) }\right.\end{array}$ & $S D$ \\
\hline Q1 & $20(38)$ & $33(62)$ & 53 & $4 \cdot 3$ & $3 \cdot 3$ & $3 \cdot 0$ & $2 \cdot 6$ \\
Q2 & $18(33)$ & $37(67)$ & 55 & $6 \cdot 6$ & $3 \cdot 7$ & $4 \cdot 6$ & $4 \cdot 0$ \\
Q3 & $14(28)$ & $37(73)$ & 51 & $6 \cdot 7$ & $3 \cdot 9$ & $4 \cdot 7$ & $5 \cdot 3$ \\
Q4 & $17(46)$ & $20(54)$ & 37 & $5 \cdot 7$ & $3 \cdot 2$ & $4 \cdot 1$ & $2 \cdot 8$ \\
Not determinable & $27(26)$ & $75(74)$ & 102 & $5 \cdot 5$ & $3 \cdot 6$ & $3 \cdot 7$ & $2 \cdot 7$ \\
\hline
\end{tabular}

$\mathrm{SD}=$ Standard Deviation

$\star$ The $p$ value for difference in the proportion positive for HPV DNA in the 4 quartiles of the menstrual cycle is 0.31 and 0.15 if those with no determinable cycle time are included.

+ One way ANOVA was used to determine if there was a significant difference in the mean pellet volume or number of cells from One way ANOVA was used to determine if there was a significant difference in the mean pellet volum
tampons specimens, during different quartile of the menstrual cycle $(p=0.02, p=0.10$ respectively). $\ddagger$ percentage for postive and negative in each quartile. 
Table 2 Pellet volume and number of cells from tampons of women with different characteristics

\begin{tabular}{|c|c|c|c|c|c|}
\hline Categorical variables & $\begin{array}{l}\text { Sub category } \\
\text { or number }\end{array}$ & $\begin{array}{l}\text { Mean pellet } \\
\text { volume } \\
\left(\mathrm{ml} \times 10^{-2}\right)\end{array}$ & $p$ value & $\begin{array}{l}\text { Mean number } \\
\text { of cells } \\
\left(\times 10^{5}\right)\end{array}$ & $p$ value \\
\hline Marital status & $\begin{array}{l}\text { Married or defacto } \\
\text { Single or separated }\end{array}$ & $\begin{array}{l}5 \cdot 5 \\
6 \cdot 1\end{array}$ & $0 \cdot 17$ & $\begin{array}{l}3 \cdot 3 \\
4 \cdot 5\end{array}$ & 0.0008 \\
\hline Smoking & $\begin{array}{l}\text { Now } \\
\text { Not now }\end{array}$ & $\begin{array}{l}5 \cdot 4 \\
6 \cdot 0\end{array}$ & 0.50 & $\begin{array}{l}3 \cdot 9 \\
3 \cdot 8\end{array}$ & 0.54 \\
\hline Educational level & $\begin{array}{l}\text { Not completed high } \\
\text { school } \\
\text { Completed high } \\
\text { school. }\end{array}$ & $\begin{array}{l}5 \cdot 4 \\
6 \cdot 0\end{array}$ & 0.22 & $\begin{array}{l}3 \cdot 6 \\
4 \cdot 1\end{array}$ & $0 \cdot 72$ \\
\hline Oral contraceptive & $\begin{array}{l}\text { Current use } \\
\text { Not using }\end{array}$ & $\begin{array}{l}6 \cdot 1 \\
5 \cdot 5\end{array}$ & $0 \cdot 21$ & $\begin{array}{l}4 \cdot 2 \\
3 \cdot 7\end{array}$ & $0 \cdot 21$ \\
\hline Pregnancy & $\begin{array}{l}\text { Ever } \\
\text { Never }\end{array}$ & $\begin{array}{l}5 \cdot 5 \\
6 \cdot 3\end{array}$ & $0 \cdot 11$ & $\begin{array}{l}3 \cdot 8 \\
4 \cdot 1\end{array}$ & $0 \cdot 24$ \\
\hline $\begin{array}{l}\text { Previously abnormal } \\
\text { Papanicolaou smear }\end{array}$ & $\begin{array}{l}\text { Ever } \\
\text { Never }\end{array}$ & $\begin{array}{l}6 \cdot 3 \\
5 \cdot 6\end{array}$ & $0 \cdot 20$ & $\begin{array}{l}3 \cdot 8 \\
3 \cdot 8\end{array}$ & 0.98 \\
\hline $\begin{array}{l}\text { Most recent } \\
\text { Papanicolaour normal }\end{array}$ & $\begin{array}{l}\text { Normal } \\
\text { Abnormal }\end{array}$ & $\begin{array}{l}5 \cdot 9 \\
4 \cdot 2\end{array}$ & 0.07 & $\begin{array}{l}3 \cdot 9 \\
2 \cdot 7\end{array}$ & 0.07 \\
\hline HPV status & $\begin{array}{l}\text { Positive } \\
\text { Negative }\end{array}$ & $\begin{array}{l}6 \cdot 3 \\
5 \cdot 5\end{array}$ & $0 \cdot 17$ & $\begin{array}{l}4 \cdot 4 \\
3 \cdot 6\end{array}$ & 0.09 \\
\hline 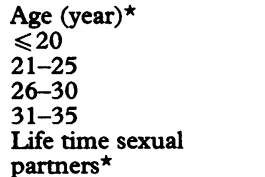 & $\begin{array}{l}27 \\
81 \\
107 \\
74\end{array}$ & $\begin{array}{l}5 \cdot 5 \\
6 \cdot 0 \\
5 \cdot 4 \\
5 \cdot 8\end{array}$ & 0.70 & $\begin{array}{l}4 \cdot 6 \\
3 \cdot 7 \\
3 \cdot 9 \\
3 \cdot 7\end{array}$ & 0.6 \\
\hline $\begin{array}{l}1-2 \\
3-4 \\
5-6 \\
>6\end{array}$ & $\begin{array}{l}91 \\
66 \\
43 \\
69\end{array}$ & $\begin{array}{l}5 \cdot 1 \\
5 \cdot 6 \\
6 \cdot 3 \\
6 \cdot 3\end{array}$ & 0.13 & $\begin{array}{l}3 \cdot 1 \\
3 \cdot 8 \\
4 \cdot 3 \\
4 \cdot 6\end{array}$ & 0.02 \\
\hline
\end{tabular}

Mann-Whitney test was used to test for a difference between the above groups.

$\star$ ANOVA used to determine if a significant difference existed.

$0.05,0.68,0.37,0.17$ respectively). The pellet volume was not significantly associated with any other variables assessed by the questionnaire (table 2).

The differences between the number of cells in different quartiles was not investigated further as there was no significant difference between these as a group $(p=0 \cdot 1)$. However, the number of cells from a tampon specimen increased with the numbers of life time sexual partners $(p=0.02)$ and was higher for a single marital status $(p=0.0008)$ (table 2). These two variables were included together in a multiple regression model and were independently associated with the number of cells.

\section{Discussion}

The findings of this study confirm our previous observations indicating that the pellet volume of a tampon specimen, but not HPV detection, vary during the menstrual cycle. ${ }^{11}$ The number of cells from a tampon specimen did not significantly change during the menstrual cycle although a trend to larger samples during the middle of the cycle was apparent.

In our study there was no difference in the prevalence of HPV among women whose samples were obtained at different times during the menstrual cycle. This is in keeping with our previous study where tampons collected weekly, for 4 weeks, were consistently positive or negative in the same women. Similar results to our own were obtained in a cross sectional study of 427 women who had cervical scrapes analysed by filter in situ hybridisation (HPV types $6,11,16,18) .{ }^{12}$ In this study the proportion of samples positive varied from $78 \%$ during week 1 or 3 to $84 \%$ during week $4(p=0.8$, for difference in the proportion with HPV detected at different weeks). ${ }^{12}$ Interestingly, in that study, specimens with inadequate DNA were more common in the first week of the menstrual cycle, coinciding with the lowest pellet volume and number of cells in our study $(p<0.05) .{ }^{12}$ In that study however this finding was restricted only to women who were using the oral contraceptive pill. ${ }^{12}$

In contrast, another study suggested that HPV detection was more likely during the second half of the menstrual cycle. ${ }^{1}$ In this study, 21 women were sampled every 5 weeks for a year and HPV 16 was detected more commonly in the second half of the cycle $(p=$ $0.005) .{ }^{1}$ This study however differed from ours, as only HPV 16 was assessed, while we used the L1 consensus primers which detect over $20 \mathrm{HPV}$ types. ${ }^{14}$ If fluctuations in HPV detection occur only with HPV 16 then we would not be expected to have detected this

Inhibition of the PCR reaction by contaminating blood may occur if samples are collected during the first week of the menstrual cycle. ${ }^{13}$ In our study, HPV detection was not less in the first quartile of the cycle, although it is possible that higher detection during this period was concealed by partial inhibition. Schneider et al, however, did report HPV detection less commonly during the first half of the cycle (includes the first week). ${ }^{1}$

The greater number the cells in tampon specimens from single women, or those with more lifetime sexual partners, was unexpected. It is possible that this finding represents a chance association although against this is the relatively low $p$ values for these associations $(0.0008$ and 0.02$)$. In addition a 
similar trend was also apparent in the pellet volume, although this was not significant. One could postulate a number of different mechanisms which could account for a greater number of cells being associated with single women, or those with more lifetime sexual partners. These may include the frequency of intercourse, inflammatory conditions or perhaps greater exposure to sexually transmissible organisms.

Under certain circumstances, the association between the size of a tampon specimen and single women, or those with more lifetime sexual partners, may exaggerate the relationship between these two variables and HPV. This is because these two variables are themselves strongly associated with HPV. ${ }^{15}$ Thus, if a technique whose sensitivity is dependent on the presence of adequate DNA is used, and the amount of DNA obtained from single women or those with more sexual partners is greater, then the association between HPV and these two variables may be exaggerated. In contrast when a technique which requires little DNA is used (such as PCR) the size of the sample obtained should not influence the chance of detecting HPV. ${ }^{8}$

The influence of the menstrual cycle on the detection of HPV DNA remains uncertain with inconsistent results from published studies. Future studies should include information on when during the menstrual cycle samples are collected in an attempt to clarify this issue.

We are grateful for the help of Ms Christine Woodburn, Drs Byrne, Permezel, Eggers, and Reti, Ms Karen Ready and the outpatient nursing staff. Funding for this study was supplied in part by The Victorian Health Promotion Foundation, The National Health and Medical Research Council, and The Royal Women's Hospital Division of Pathology, Research and Education Fund.
1 Schneider A, Kirchhoff T, Novak ER, Woodruff JD, eds. Meinhardt G, et al. Repeated evaluation of human papiomavirus 16 status in with a history of normal

2 Koutsky LA, Holmes KK, Critchlow CW, et al. A chort study of the risk of cervical intraepithelial neoplasia grade 2 or 3 in relation to papillomavirus infection N Engl F Med 1992;327:1272-8.

3 Moscicki AB, Palefsky JM, Gonzales J, et al. Colposcopic and histologic findings and human papillomavirus DNA test variability in young women positive for HPV DNA F Infect Dis 1992;166:951-7.

4 Frost JK. Gynecologic and Obstetric cytopathology. In Novak ER, Woodruff JD, eds. Novak's Gynecologic and Obstetric Pathology, with clinical and Endocrine relations. 7th ed. Philadelphia. WB Saunders 1974:649.

5 Brown DR, Fife KH. Human papillomavirus infections of the genital tract. Med Clin North Am 1990;74:1455-85.

6 Pater A, Bayatpour M, Pater MM. Oncogenic transformation by human papillomavirus deoxyribonucleic acid in the presence of progesterone or progestins from oral the presence of progesterone or progestins from

7 Chan W-K, Klock G, Bernard H-U. Progesterone and glucocorticoid response elements occur in the long control regions of several human papillomaviruses involved in anogenital neoplasia. $\mathcal{F}$ Virol 1989;63:3261-9.

8 Fairley CK, Chen S, Tabrizi S, Quinn M, Garland SM The influence of the menstrual cycle on tampon specimens. F Infect Dis 1992;166:1199-200

9 Sambrook J. Fritsch EF. Maniatis T. Molecular Cloning: Laboratory Manual. 2nd Ed. Cold Spring Harbour. NY: Cold Spring Harbor Laboratory Press. 1989.

10 Resnick RM, Cornelissen MT, Wright DK, et al. Detection and typing of human papillomavirus in archival cervical cancer specimens by DNA amplification with vical cancer specimens by DNA amplification with concensus primers. I Natl Cancer Inst 1990;82:1477-84

11 Bauer HM, Hildesheim A, Schiffman MH, et al. Determinants of genital human papillomavirus infection in low-risk women in Portland, Oregon. Sex Transm Dis. 1993;20:274-8

12 McNicol PJ, Guijon FB, Paraskevas M, Heywood E, Gray MJ, Brunham RC. Effect of the menstrual cycle on detection and typing of human papillomavirus in uterin cervical cells. Am f Obstet Gynecol 1990;162:1037-41.

13 Gravitt PE, Manos MM. Polymerase chain reaction-based methods for the detection of human papillomavirus DNA. In: Munoz N, Bosch FX, Shah KV and Meheus A, eds. IARC publication No 119 The epidemiology of human papillomavirus and cervical cancer. Oxford 1992:121-34.

14 Roman A, Fife KH. Human Papillomaviruses: Are we ready to type?. Clinical Microbiology Reviews. 1989;2: 166-90.

15 Ley C, Bauer HM, Regingold A, et al. Determinants of genital human papillomavirus infection in young women. $\mathcal{f}$ Nat Cancer Inst. 1991;83:997-1003. 